\title{
Abstracts of Memoirs.
}

RECÔRDTNG WURK DONE AT THE PLYMOUTH LABORATORY.

\section{Pinnotherion vermiforme Giard and Bonnier, an Entoniscid infecting Pinnotheres pisum.}

By D. Atkins.

Proc. Zool. Soc., Lond., Part 2, 1933, pp. 319-363.

Pinnotherion vermiforme infects Pinnotheres pisum from the Camel Estuary, Padstow, North Cornwall.

The males are not restricted in their occurrence to the body of the female, as apparently they are in other genera of Entoniscidæ, but occur isolated in the host, as do also the cryptoniscan larvæ. Of the total Pinnotheres examined $27.69 \%$ were infected. Infection with the male parasite alone was $26.85 \%$, with the female (sometimes with males present in addition) $0.84 \%$. The proportion of the sexes in P. vermiforme was $97 \cdot 67 \%$ males and $2 \cdot 33 \%$ females. The presence of the adult female causes partial to almost complete atrophy of the gonad of the host. At Padstow the female parasite has been found in the female host only; the male has on two occasions been found in the male host.

The relation of the parasite to its host and the possible manner of respiratory exchange is discussed.

The female and male $P$. vermiforme are described and figured, and, so far as material allowed, the epicarid and cryptoniscan larvæ.

D. A.

The Photo-electric Measurement of the Penetration of Light of Various Wave-lengths into the Sea and the Physiological Bearing of the Results.

By W. R. G. Atkins and H. H. Poole.

Phil. Trans. Roy. Soc. B., 1933, Vol. 222, pp. 129-164.

Using a potentiometer-telephone method with sodium, potassium and thin film caesium cells, and light filters, the coefficient of absorption was found to be : for the near ultra-violet, 0.390 ; blue, 0.140 ; green, 0.155 ; yellow (not including red), $0 \cdot 164$; orange-red, 0.435 ; red, 0.480 and deep red, 0.567. It follows that the sub-surface illumination is reduced to 0.001 per cent at $30,82,74,70,26,24,20$ metres, respectively. The figures given may be taken as typical of the English Channel ten miles 
out. For the clearest water found, twenty miles from land, the coefficient was 0.077 , for blue light. Correction factors are given for certain reflection losses between air-glass and air-water surfaces and for instru.mental effects. The loss at the air-water surface appears to be small in calm water, but is appreciably increased by wind.

The heating of the water below the thermocline may be attributed to the absorption of light, from yellow to violet.

The ratio of the total vertical to the diffuse vertical light, in air, increases from $2 \cdot 2$, for near ultra-violet, to $5 \cdot 5$ for deep red, as determined under a clear blue sky with sun at $52^{\circ}$ altitude.

Data, available from the work of Marshall and Orr, for the evolution of oxygen by diatoms, yield values for the absorption coefficient chiefly between $0 \cdot 15$ and $0 \cdot 20$, corresponding to that for light from blue to yellow.

The spring increase in diatoms was not found to decrease light penetration. At a maximum the mean thickness of diatoms traversed in a $10 \mathrm{~m}$. water column is only $0.25 \mathrm{~mm}$. and is probably nearer one-tenth of that on an average.

The absence of red light from the deeper water may be expected to have a bearing on the colour vision of certain fish.

Hulburt's coefficients have been used to show that even in the clearest ocean water the anti-rachitic portion of the spectrum is reduced to 1 per cent of its sub-surface value at $1 \cdot 1-2 \cdot 2 \mathrm{~m}$., according to wave-length and to 0.001 per cent at from 2.9 to $5.5 \mathrm{~m}$. This has an obvious bearing on the origin of vitamin $\mathrm{D}$ in fish-liver oils.

W. R. G. A.

Osmotic and Ionic Regulation in the Shore Crab, Carcinus mxenxs, with notes on the Blood Concentrations of Gammarus locusta and Ligia oceanica.

\author{
By J. B. Bateman. \\ Journ. Exp. Biol., Vol. X, 1933, pp. 355-371.
}

Chloride and vapour pressure data for the body fluids of Carcinus living in various strengths of sea-water were obtained, Duval's observation that " osmotic" regulation is abolished in concentrated sea-water being confirmed. Then the effect of "osmotic" and "ionic" forces on the normal regulation was studied by immersing crabs in sea-water containing respectively foreign non-electrolytes and electrolytes. The substances added showed interesting specific effects, glucose in particular causing a large increase in blood chloride, but in generai they supported the belief that the regulating membrane (presumably the gill) is impermeable to water. This is in agreement with other experiments which are described. Miscellaneous experiments on the effects of cyanide, $\mathrm{pH}$, and temperature 
are given, with a discussion of the mechanism of regulation and the thermodynamic work involved.

A direct study of the body fluids demonstrated the high degree of osmotic independence of Ligia for short periods of immersion and its breakdown after longer periods. Gammarus appears to regulate in much the same way as Carcinus.

J. B. B.

\section{The $\mathrm{CO}_{2}$ Dissociation Curves and the Buffering of Crab's Muscle and Nerve Preparations.}

By S. L. Cowan.

Journ. Exp. Biol., Vol. X, 1933, pp. 401-111.

Crab's muscle and nerve preparations, which had been previously soaked in aerated sea-water for an hour, were brought into equilibrium with different $\mathrm{CO}_{2}$ nitrogen mixtures of known composition in a modified Barcroft apparatus and then the combined $\mathrm{CO}_{2}$ was measured after acidifying the tissue. From the $\mathrm{CO}_{2}$ dissociation curves so obtained, by means of the Henderson-Hasselbalch equation, the $\mathrm{pH}$ of the preparations under known $\mathrm{CO}_{2}$ pressures was calculated.

For muscle and for nerve the relation between $\mathrm{CO}_{2}$ pressure and $\mathrm{cH}$ was almost linear over the greater part of the range.

$\mathrm{It}$ is probable that the $\mathrm{CO}_{2}$ binding capacities and the $\mathrm{pH}$ of the tissues are altered by the preliminary soaking in sea-water, and that the figures given would not hold good (for muscle and nerve) in the intact animal.

S. L. C.

\section{The Relation between Somatic and Germ Cells in the asexually produced polyps of the Polyzoan Alcyonidium gelatinosum.}

\section{By G. H. Faulkner.}

Annals and Magazine of Natural History, Ser. 10, Vol. XI, 1933, p. 255.

In the development of the asexually produced polyp of Alcyonidium gelatinosum, certain cells are very early set aside, and remain undifferentiated. They proliferate actively, and contribute to the growth of the alimentary canal ; during the period of growth they form a morula-shaped mass projecting into the body cavity, attached to the cæcum of the alimentary canal adjacent to the attachment of the funiculus. In the sexual season cells persisting from this group give rise to the female sexcells. (The origin of the male germ-cells was not traced.) These cells are inter-epithelial in position, lying between the basement membrane of the endoderm and the peritoneum. They are considered to be homologous with the neoblasts of Annelids.

G. H. F. 


\section{Recherches Sur les Hemérythrines. By Marcel Florkin.}

Arch. Int. Physiol., 1933, Vol. 36, pp. 247-328.

The haemerythrins, respiratory proteins found in the red cells in the coelomic fluid of the Sipunculids, are typical globulins, crystallizing in the rhombohedric system. The spectrum of the haemerythrin of Sipunculus nudus is quite different from the spectra of all haem derivatives, and in ertain aspects more similar to the Haemocyanin (hemsbyanius) spectrum. The ratio $\frac{\text { Iron }}{\text { Oxygen }}$ is different from this ratio for the oxygenation of Haemoglobin. In conditions where Haemoglobin is transformed into Carboxy-haemoglobin, there is no combination of $\mathrm{CO}$ to Haemerythrin. The respiratory function of the cœlomic fluid of Sipunculus is analysed, and the Bohr effect shown to be absent. The different peculiarities of this cœlomic fluid show many correlations with the characters and habits of the animal considered.

M. F.

\section{Blood Circulation of Animals possessing Chlorocruorin.}

\section{By H. Munro Fox.}

Proc. Roy. Soc., Ser. B Vol. CXII, 1933, pp. 479-495.

Most blood-vessels of sabellids and serpulids are rhythmically contractile, including all the blind-ending capillary vessels in crown, body wall, and coelom. In the continuous vessels the blood is circulated by peristalsis, in the capillaries there is an ebb and flow of the blood. The rhythmic contractions of the vessels are independent of the central nervous system. The simultaneity of contractions in the vessels of the separate filaments of the crown is controlled by a ganglion at the base of each half of the crown. After sabellid worms have retired into their tubes for over half an hour, the contractions of their blood-vessels cease. The contractions recommence as soon as even the tip of the crown projects beyond the end of the tube. In spite of the cessation of blood circulation, Spirographis can remain uninjured for eight hours in its tube when the latter is artificially closed. After eight hours the animal makes a new anterior lateral opening in the closed tube and re-expands its crown. When sabellids or serpulids, removed from their tubes, are put into seawater the $\mathrm{pH}$ of which has been brought below 6.0 by the addition of carbon dioxide, the contractions of their blood-vessels stop. Neither water acidified with hydrochloric acid to the same $\mathrm{pH}$ as the water containing carbon dioxide, nor water lacking dissolved oxygen, produces this effect. The inhibition of blood-vessel contractions due to carbon 
dioxide is reversible when the animals are replaced in pure sea water. Carbon dioxide does not inhibit the blood-vessel contractions through a nervous reflex, it causes an internal accumulation of carbon dioxide which acts directly on the blood-vessel walls. It is probable that the cessation of blood-vessel contractions when sabellids have retired into their tubes is due to the accumulation of carbon dioxide in the water between the filaments of the crown. The threshold $\mathrm{pH}$ for the inhibition of bloodvessel contractions of Dasychone was determined in $(a)$ sea-water containing dissolved carbon dioxide, $(b)$ sea-water of abnormally high alkali reserve containing carbon dioxide, and (c) sea-water acidified with hydrochloric acid. From these data it was concluded that both carbon dioxide and hydrogen ions are concerned in the inhibition, but that the former is more important than the latter. Carbon dioxide also causes the reversible inhibition of contractions in the following cases : $(a)$ the dorsal blood-vessel of Nereis; $(b)$ the hearts of Daphnia, Artemia, Chlœon nymphs, Phallusia, chick embryos; $(c)$ the contractile vesicles of Limax embryos.

H. M. F.

\section{Einige Untersuchungen über die Eiweissverdauung bei Gastropoden. By Sven Hörstadius. \\ Biologisches Zentralblalt, Vol. 53, 1933, pp. 645-650.}

The investigation was made in Utrecht, Naples, and Plymouth, the last place thanks to a Ray Lankester Investigatorship. Several statements of phagocytosis in Gastropods have proved to be wrong. Previous investigators found ingested carmine particles in mid-gut gland cells (Helix, Planorbis). A close examination shows that, instead, granules in the cells have been stained red by carmine, that has gone into solution and thus passed into the cell by means of diffusion. Proteolytic enzymes are active in the gut, as fibrin is dissolved. Colloidal gold particles of a certain size, embedded in small pieces of fibrin, were never ingested by the cells.

Also the previous result, that chloroplasts are ingested by Aplysia cells, has proved to be based on a mistake. No phagocytosis takes place, but chlorophyll diffuses into the cells and stains granules green and brown.

On the other hand, phagocytosis was stated to occur within Pleurobranchea, by aid of the gold particle method, and within Hermæa. The latter was fed partly on Codium, partly on Bryopsis, two algæ with chloroplasts of very different size. Both kinds of chloroplasts were found in the liver cells.

S. H. 
On Ceratotrema Furcolabiata n.g. et n.sp. and Hemipera sharpei n.sp. Two New Digenetic Trematodes of British Marine Fishes.

\section{By E. Idris Jones.}

Parasitology, Vol. $X X V, 1933, p p$. 248-254.

(a) Ceratotrema furcolabiata n.g. et n.sp. was found in the ccelom of Onos mustela at Plymouth. This is the third trematode recorded from the cœlom of fishes.

Generic Diagnosis. Length $7 \cdot 3-7.8 \mathrm{~mm}$. Greatest width $1.7 \mathrm{~mm}$. Abdomen completely invaginated into body. Anterior sucker approximately two-thirds size of ventral sucker; average measurements 0.57 and $0.77 \mathrm{~mm}$. respectively. Anterior sucker with three cushion-like projection into lumen, one anterior and two postero-lateral. Lip dorsally situated, very muscular, and strongly bifid, not overhanging the mouth. Ventral groove present. Testes two, oval, situated opposite each other immediately posterior to ventral sucker. Ovary spherical, posterior to testes. Receptaculum seminis present. Vitellaria arranged in two groups posterior to ovary; limbs of vitellaria short and thick and split up to base. Metraterm long, reaching almost to ventral sucker. Eggs green, numerous, $23 \mu \times 11 \mu$.

Host; Onos mustela, in cœlom. Types in the British Museum (Nat. Hist.). Its systematic position is indicated.

(b) Hemipera sharpei n.sp. Found under the operculum of Cepola rubescens at Plymouth.

Specific Diagnosis. Host ; Cepola rubescens. Situation; under gillcover. Large and robust. Bluntly rounded. Length, $4 \cdot 77-4 \cdot 85 \mathrm{~mm}$. Anterior sucker, $0.372 \mathrm{~mm}$. Ventral sucker, $0.744 \mathrm{~mm}$. Laurer's canal present and prominent receptaculum seminis. Eggs not curved and with long filaments not intertwining. Egg measures $100 \mu \times 38 \mu$.

E. I. J.

\section{Fertilisation and Egg Formation in a Digenetic Trematode, Podocotyle atomon.}

By E. Idris Jones.

Parasitology, Vol. XXIV, 1933, pp. 545-547.

An account is given of the fertilisation of the ova and of subsequent egg formation in Podocolyle atomon. The times taken for the various processes are given.

E. I. J. 
Studies on the Monogenea (Trematoda) of Plymouth. Microbothrium canicule (Johnstone, 1911).

By E. Idris Jones.

Parasitology, Vol. XXV, 1933, pp. 329-331.

Microbothrium caniculce was found at Plymouth for the first time on Scyllium canicula. It had previously been described by Johnstone as Paracotyle caniculce n.sp. in 1911. A detailed description of the morphology of the species is given and its position in the genus Microbothrium Olsson 1869 indicated.

E. I. J.

\section{The Hirudinea of Plymouth. Part I.}

\section{By W. H. Leigh-Sharpe.}

Parasitology, Vol. XXV, 1933, pp. 255-262.

This account deals with the Ichthyobdellidæ. A list is given of those hitherto found at Plymouth, and a description: of some presumably young forms found on skate: of two new species, Branchellion borealis, having but 31 pairs of gills, one specimen, taken by Mr. G. A. Steven on a skate; and Janusion scorpii, perhaps the Platybdella scorpii of Malm, occasionally found by the author on Cottus scorpius.

W. H. L.-S.

\section{Studies on the Relation between Organism and Environment.}

\section{By J. H. Orton.}

Transactions of the Liverpool Biological Society, Vol. XLVI, 1932, pp. 1-16.

In this short paper a summary is given of the author's experiments and observations on marine animals which demonstrate differences in the manifestation of the fundamental processes of feeding, growing, breeding, sex, and survival in different environments. It is therefore adduced that variation in the environment-and still more permanent non-lethal changes - may be expected to bring about definite changes in the organism. From the general fitness of the organism to the environment it would appear that such adaptive changes have become fixed in some manner which still remains to be demonstrated.

The author gives some hitherto unpublished observations on the characters of shells of Patella vulgata L.* The notably wide range of

* The adults (i.e. with shells above about $3 \mathrm{~cm}$.) were normal common limpets ; many colour varieties occurred among the young individuals and traces of the coloured rays could be seen in the smaller thin-shelled low-water adults. There does not appear to be any valid reason for recognising the low-water form from this locality as the separate species, $P$. intermedia Jeffries. Typical forms of the variety (or species) $P$. athletica Bean do not occur in the locality in the habitats sampled. (See Journ. Mar. Biol. Assoc., N.S., vol. XV, p. 860.) 
variation at all sizes in the relation between the mean of the length $(\mathrm{L})$ and breadth $(\mathrm{B})$ of the shell—and height $(\mathrm{H})$-is shown.

A close comparison of samples of limpet shells from respectively highand low-water situations on Looe Island is made, and constant differences are demonstrated in the following relations: length and height; length and mean axis (mean axis $\left.=\frac{\mathrm{L}+\mathrm{B}+\mathrm{H}}{3}\right)$; length and weight ; approximate internal area of shell and weight at given corresponding lengths; weight and apical thickness of the shell for given lengths. The latter values are higher in all cases for high-water limpets.

The shape of a sample of shells of a given range in size is definable by

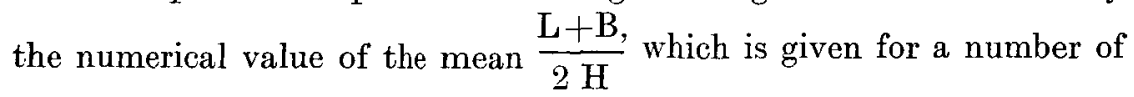
samples from high- and low-water situations; the low-water samples give values constantly higher than those from high water. The highwater samples were taken from various selected situations on the south coast of England; it was found that the greater the exposure of the shells to dessication the lower was this numerical value for shell-shape. In an examination of limpet habitats extending over a large portion of the coast of Devon and Cornwall, this effect of dessication was confirmed except for a small population of limpets on an island adjacent to the Gas Works, Teignmouth Estuary, where relatively tall shells are found at about high-water neaps.

The explanation is offered that the shape of the shell in any habitat is due ultimately to habit; in situations exposed to dessication the animal must cling tightly to the substratum to maintain a moist condition of the gills, in damp situations the animal does not need to remain apposed to the substratum; these habits are known. Since increase in shell area occurs at the edge of the shell, and limpets may be assumed to grow shell while apposed to the substratum, a smaller perimeter increment of growth will be made by an apposed limpet than by one relaxed or not apposed. Hence limpets more constantly apposed to the substratum grow a higher shell than those relaxed in damp situations.

Different laws of growth are indicated for young and older individuals; first approximations are given. The studies are being continued, and other results will be communicated later.

J. H. O. 


\section{Experiments on the Suitability of some Rectifier Photo Cells for the Measurement of Daylight.}

By H. H. Poole and W. R. G. Atkins.

Sci. Proc. Roy. Dublin Soc., 1933, Vol. 20, pp. 537-546.

In using rectifier cells it is necessary to know the form of the current illumination curve. The latter depends on the resistance of the external circuit, so a low resistance galvanometer should be used. A shunt was designed to reduce the galvanometer sensitivity without affecting its resistance. Temperature effects are important in some cells. The wavelength sensitivity curves of several cells were studied, that of the Bergmann selenium cell is by far the closest in form to that of the human eye. This selenium cell is also relatively the most stable.

W. R. G. A.

\section{Reversal of the Current from a Cuprous Oxide Photo Cell in Red Light. By H. H. Poole and $\dot{\text { W. }}$ R. G. Atkins. \\ Nature, 1933, Vol. 131, pp. 133 and $\mathbf{5 4 7}$.}

The effect, observed by Auger and Lapicque, was found to exhibit a maximum at $6280 \mathrm{~A}$. In the marginal region of the cell it amounted to 10.6 per cent of the maximum sensitivity of the cell for the direct current, which occurred near $5000 \mathrm{~A}$. The central region gave no reversal. The explanation offered is that the normal effect is located at the front surface of the copper-oxide film, whereas the reverse effect is due to red light penetrating the film to the copper plate behind, but only where the film is thin, as at the margin. The values relate to an equal energy spectrum. At one spot in the marginal region the reverse effect was 28.5 per cent of the maximum direct current from the same region.

W. R. G. A. 